\title{
A patient's diary: episode 18 - meet Mrs Gland's American cousin
}

So here I am over in England having a little vacation for the sake of my health. Now I am not saying that England is such a healthy spot, although I have nothing against the place personally. But the fact is that I need to cross the ocean a little hastily in order to avoid the attentions of certain citizens known to one and all in my hometown as Harry the Horse and Spanish John. These characters are hard guys indeed and they are sored up with me more than somewhat on account of a sure-fire certainty at the racetrack which I passed on to them with the best of intentions. Unfortunately the sure-fire certainty turns out to be a real bum steer and blows in the first race at Belmont whereupon Harry the Horse and Spanish John are anxious to interview me. In fact, they are putting it around that when they catch up with me they are about to take serious risks with my health with a couple of John Roscoes that they carry in their hip pockets. Now, I am totally opposed to illegality of every kind, but I take a special objection to violence against my person. In fact this is the kind of excitement I want no part of.

So here I am in England, enjoying the hospitality of my cousin Hilda and her husband Norman, known to one and all in this town as Norman the Gland. Now this Norman is an amiable guy but he is very worried about his internal organs. His liver, he tells me, is full of holes like a colander and his pancreas is put through the mincing machine. He has other organs, some of which I never hear of, that are so thoroughly mashed as to resemble a potato latke or even a Hungarian goulash and it is a probable 12-7 that he will haul off and die of some disease or other at any moment. All this talk of premature retirement reminds me of the plans that Harry the Horse and Spanish John are making to rearrange my own internal organs, and soon I begin to feel a little sick myself. I think maybe I should hire myself a Limey croaker to give me a checkup. When I confide as much to Norman the
Gland he guffaws merrily and says, 'You Americans are always wanting checkups.' He then tells me that his own medico, by the name of Doc Teacher, is known to one and all in this town as a prominent physician and he offers to make me an introduction.

So Norman and I go downtown to Doc Teacher's place which is called The Old Surgery. In charge of the front office is a long frazzled old doll of about 90 years of age with gold-framed half spectacles, who Norman tells me is called Miss Ivy Flagg. When Norman says to her, 'Here is my dear cousin-in-law, who comes all the way across the ocean for his health and is very much in need of old Doc Teacher's opinion,' Miss Ivy Flagg looks at a great big screen she has in front of her and says 'Am I a temporary resident?' About the meaning of this question I am not too sure. I tell her that, if certain characters in my hometown have their way, my residence on this entire planet will indeed be temporary. She does not catch my meaning but merely stares at me and says she has no appointments left on her screen. She does not say this very nicely and it seems to me that she is a very stern old doll of the kind I do not wish any truck with. In fact, I do not want any part of her at all. She looks like she would think nothing of boffing a guy on the kisser if he uses profane language, so I keep my discourse polite, as I always do when talking to fierce old dolls such as she.

I hate to trouble a busy guy such as Doc Teacher, I say, who undoubtedly is run off his feet fixing the health of all the prominent citizens in this town, but I myself am well known to one and all as a guy who suffers with blood pressure. Right now, I can tell from the throbbing in my noggin that my blood pressure is way up in the paint cards and liable to go north through the top of my bean. I am not generally a chalk-eater, I tell Miss Ivy Flagg, but I will lay any man odds of 40-1 that if I do not get to see Doc Teacher in the next half an hour my next trip will be to the refrigerator. Furthermore, I say, I am so discouraged that I do not even feel like taking a little of the price against me to show. Not being a horse-player at heart, the old doll does not follow my reasoning, but I think she is impressed by the strength of my feelings, because she gets on the blower to old Doc Teacher himself. She whispers to him that she has here one mean character such as will terrify old dolls of a nervous disposition such as herself. It then appears that Doc Teacher discovers he has a number of cancellations, as a number of citizens are suddenly recollecting that they have other important appointments elsewhere.

Although Doc Teacher is never in New York City it seems he is interested in my hometown more than somewhat. He sees a musical show name of Guys and Dolls and also he reads many books so he is familiar with places such as Mindy's restaurant at 17th and Broadway. He wants to know if tough guys are still seen to cry into their goulash there after a hard day at the track. Furthermore, He would like to know if Good Time Charlie still runs the speakeasy on West 47th Street. After concluding his enquiries, Old Doc Teacher gets down to business. He puts a gag on my arm and tells me my blood pressure is higher than a cat's back and I should try to avoid excitement of any kind if I wish to stay one step ahead of the undertaker. He gives me advice about the perils of cigars and whisky but I assure him that I consume only those of the highest quality. Then he gives me a prescription for some pills and tells me I can register as a temporary resident of this town. Unless I'd like to be a Private Patient in which case I owe him 100 dollars. I consider this proposition and tell him that I prefer it if he claims his scratch from the Federal Authorities and I will use the 100 bucks to bet on a certainty which I hear is running in the fourth at Newmarket.

Old Doc Teacher is a most genial guy. He says that when he visits the US he plans to look me up because he is anxious 
to see around and to participate in the floating crap game in back of the cigar store on 44th. Or, alternatively, in the Biltmore Garage if, as seems likely, the back of the Police Station continues to be out. All this friendly nattering does me a lot of good and I can feel that my blood pressure is already creeping down to normal. We say a cordial farewell and on the way home I tell cousin Norman that in my opinion old Doc Teacher is very up and coming in the National Health Racket and is set to be, provided he avoids bad company and pays his dues, the most respected croaker in town.

We are grateful to John Salinsky for these extracts from Norman Gland's diary.

DOI: 10.3399/bjgp08X302871

\section{Launch of the Association for Young People's Health}

Growing concerns about the health of young people continue. The UNICEF report in 2007 placed Britain at the bottom of the 21 richest countries in terms of how children and young people rated their emotional wellbeing. ${ }^{1}$ UK teenagers undertake more risky behaviour than any other European nations' youth, increasing the harm associated with unprotected sex, smoking, alcohol and substance abuse along with unhealthy eating habits. Some improvements have been made. We now have the lowest rate of underage conception for 20 years, ${ }^{2}$ which is clearly good news. However, one interpretation of the statistics ${ }^{2}$ still estimates a current rate of 1 in 50 UK schoolgirls falling pregnant which seems like poor progress in an era of increased focus on sexual health, informed by pivotal documents such as the NSF Framework for Children, Young people and Maternity Services (2004) and the RCGP initiative Getting it Right for Teenagers in Your Practice. ${ }^{3}$ Obesity is also on the rise and will continue to compromise the health of young people for years to come.

There is no doubt that the statistics for young people's health are worrying but they are not being ignored. February 2008 saw the launch of a new multidisciplinary organisation The Association for Young People's Health (AYPH) with an inaugural meeting held at The Institute of Child Health. The aims of the AYPH are multi fold and include advocacy, dissemination of information, and affiliation with international bodies concerned with the health of young people. The organisation acknowledges the importance of supporting and promoting research in this area and its multidisciplinary base will facilitate translational research. The RCGP Adolescent Task Group has been a key driver behind the development of the organisation and under the leadership of Dr Dick Churchill has been a major player in the production of training materials in adolescent health. The Adolescent Health Project is an e-learning initiative aimed at providing training for post-registration health professionals from a range of disciplines and seeks to address the gap in training opportunities that currently exists.

No one denies that working with teenagers is challenging but the marginalisation of their needs and the lamentable state of health that many endure, notably in terms of poor emotional and mental health with only $25 \%$ of mental disorders detected in community samples, ${ }^{4}$ behoves us to be more proactive. This is where the AYPH seeks to raise the profile, increase our knowledge base and be an important advocate. Membership is currently free for this first year - please log onto http://www.youngpeopleshealth.org.uk.

\section{Jane H Roberts}

\section{REFERENCES}

1. UNICEF. Child poverty in perspective: An overview of child well-being in rich countries. Florence, Italy: The United Nations Children's Fund, 2007.

http://www.unicef-icdc.org/presscentre/presskit/ reportcard7/rc7_eng.pdf (accessed 12 May 2008).

2. Office of National Statistics and Teenage Pregnancy Unit, 2008. Teenage pregnancy. London: Department for Children, Schools and Families, 1995.

http://www.everychildmatters.gov.uk/teenagepregnan cy/ (accessed 12 May 2008)

3. Royal College of General Practitioners and Royal College of Nursing. Getting it Right for Teenagers in your Practice. London: RCGP \& RCN, Department of Health, 2002.

4. National Institute for Clinical Excellence. Depression in children and young people. London: NICE, 2005.

DOI: 10.3399/bjgp08X302880 